\title{
Anthropometric measurements of foot length and shape in children 2 to 7 years of age
}

\author{
OZREN VRDOLJAK ${ }^{1}$ \\ MIRJANA KUJUNDŽIĆ TILJAK² \\ MISLAV ČIMIĆ ${ }^{3}$ \\ ${ }^{1}$ Children's Hospital Zagreb \\ Department of Orthopaedic Surgery, Klaićeva 16 , \\ 10000 Zagreb \\ ${ }^{2}$ School of Public Health „Andrija Štampar" \\ University of Zagreb, Department of Medical Statistic \\ Epidemiology and Medical Informatics \\ ${ }^{3}$ University Hospital Centre Zagreb \\ Clinic of Orthopaedic Surgery
}

\section{Correspondence:}

Ozren Vrdoljak

E-mail:0zren1974@gmail.com

Keywords: child, foot, anthropometry

Received September 16, 2016.

Revised February 09, 2017.

Accepted March 03, 2017.

\begin{abstract}
Background and purpose: A child's foot changes shape and proportions during growth so that it adapts to function. The purpose of this article is to determine foot length in children aged 2-7 years as a fundamental unit for measuring the growth of the foot, with which it will be able to compare other anthropometric measures of the foot. Determination of the shape of the foot and interpretation of the growth curve of the foot in length are important for standardization of the foot.
\end{abstract}

Materials and methods: The study was conducted on a sample of 2745 children, totalling 5490 feet. Of this, there were 1375 boys and 1370 girls. The population encompassed children aged 2 (1.50-2.49) to 7 (6.50-7.49) years and subjects were divided into 6 age groups. Foot length was measured by measuring tape, while shape was determined clinically.

Results: There is no difference in length and shape between the left and right feet of boys and girls across all age and sex groups, and the most common shape was the Egyptian foot shape. The foot grows most rapidly between the $2^{\text {nd }}$ and $3^{\text {rd }}$ year. From the $3^{\text {rd }}$ to $6^{\text {th }}$ years, the foot grows by approximately $1 \mathrm{~cm}$ yearly, while in girls between the $\sigma^{\text {th }}$ and $7^{\text {th }}$ year the foot grows $5 \mathrm{~mm}$.

Conclusions: Foot length is the basis for size comparison and determination offoot shape type. The results obtained demonstrate that the foot grows in length equally yearly and that there is no difference between the left and right feet.

\section{INTRODUCTION}

I ength and shape of the foot has changed with evolution, adapting to the upright posture of man and the change in manner of weight bearing. The tarsus has increased by over $50 \%$ in length of the foot, and with the development of the transverse and longitudinal arches, a foot for walking and running developed, as opposed to climbing and grasping. The greatest changes in length and shape of the foot occur in the earliest years, where the foot must develop sufficiently in width to allow for balance while a child learns to walk $(1,2,3)$. The length of the foot of a child during growth reaches its final dimensions more proportionally than any other element of the body during growth. The foot of a girl 1 year old and that of a boy 18 months old approaches $50 \%$ of their final length at the end of growth because a wide base of the foot compensates for the weakness and lack of muscle coordination in a child (4). Three main shapes of the forefoot have developed based on toe length and the relative proportion amongst the toes: Egyptian, square, and Greek. In the Egyptian type, the great toe is largest, followed by each 
Table 1: Distribution of the study population according to age and sex.

\begin{tabular}{|c|c|c|c|c|c|}
\hline \multirow[t]{2}{*}{ Age - years } & \multicolumn{2}{|c|}{ Boys } & \multicolumn{2}{|c|}{ Girls } & \multirow[t]{2}{*}{ Total feet } \\
\hline & Right foot & Left foot & Right foot & Left foot & \\
\hline $1.50-2.49$ & 149 & 149 & 242 & 242 & 782 \\
\hline $2.50-3.49$ & 181 & 181 & 214 & 214 & 790 \\
\hline $3.50-4.49$ & 263 & 263 & 221 & 221 & 968 \\
\hline $4.50-5.49$ & 245 & 245 & 196 & 196 & 882 \\
\hline $5.50-6.49$ & 288 & 288 & 259 & 259 & 1094 \\
\hline \multirow[t]{2}{*}{$6.50-7.49$} & 249 & 249 & 238 & 238 & 974 \\
\hline & 1375 & 1375 & 1370 & 1370 & 5490 \\
\hline
\end{tabular}

of the lesser toes. The great toe is shorter than the second toe in the Greek foot shape, while in the square foot shape the great toe and all lesser toes are practically inline. In children, the Egyptian foot type is commonest, followed by the Greek type, and very rarely the square type. Foot length in growing children is standardized in individual countries and varies according to geographic position and ethnic differences. Foot length is taken as a fundamental measuring unit which allows for following the growth of the foot, and can be used to compare other anthropometric measures which would be important for standardization of foot sizes in children.

\section{STUDY GOAL}

The goal of this study is to determine the length and shape of the foot in male and female children of preschool age (2-7 years) in the Republic of Croatia. Comparison between right and left feet in individual age/sex subgroups and interpretation of the growth curve of the foot in length were also performed.

\section{STUDY POPULATION AND METHODS}

The study is a continuation of the research presented in „Anthropometric measurements of the foot during growth “ (5) in which the group sample size of male and female children was defined as was an equal regional distribution of subjects established. The study encompassed preschool children living in the Republic of Croatia from the Zagreb County and the Split-Dalmatian County, and was conducted on a sample of 2745 children, totalling 5490 feet. Of this, there were 1375 boys and 1370 girls. The sample population encompassed children from 2 (1.50-2.49) to 7 (6.50-7.49) years and subjects were divided into 6 age groups. In the first age group (2 years of age) there were 242 girls and 149 boys; in the second age group ( 3 years of age) there were 214 girls and 181 boys; in the third age group ( 4 years of age) were 221 girls and 263 boys; in the fourth ( 5 years of age) were 196 girls and 245 boys; in the fifth age group ( 6 years of age) were 259 girls and 288 boys; and in the sixth age group ( 7 years of age) were 238 girls and 249 boys (Table 1).

Foot length was measured using measuring tape in the standing position while weight-bearing, while foot shape was determined clinically. The Kolmogorov-Smirnov test was used to describe the distribution of foot sizes. Statistical workup was conducted using the computer program STATISTICA, StatSoft, Inc., ver. 10.0

\section{RESULTS}

The distribution of lengths of the right and left foot in boys and girls of all 6 age groups was analysed in detail. No statistically significant difference was observed between lengths of right and left feet among girls and boys across all age groups. The foot grows fastest in length between ages $2-3-$ by $1.8 \mathrm{~cm}$ in girls and $1.6 \mathrm{~cm}$ in boys. From the $3^{\text {rd }}$ to $6^{\text {th }}$ year, the foot grows rather uniformly, by about $1 \mathrm{~cm}$ yearly, while the slowest growth took place in girls between their $6^{\text {th }}$ and $7^{\text {th }}$ year (Table 2,3). The dynamic of foot length growth is determined by an exponential curve. The difference in foot shape in individual sex-age groups are negligible. The Egyptian foot type was the most prominent across all groups, being equal in boys and girls (80\% in boys, $79 \%$ in girls), the Greek type appeared in $15 \%$ of boys and $18 \%$ of girls, while the square type was found in only $5 \%$ of boys and $3 \%$ of girls (Table $4,5)$. No statistically significant difference was found in shape between right and left feet.

\section{DISCUSSION}

Few studies determining foot shape and length have been published in Croatian and the world literature in general. A group of authors in 1990 conducted a study in Croatia to determine the shape of feet (6). The study encompassed 500 randomly selected adult subjects. Their study showed that $90 \%$ of their study population had Egyptian type feet, and that $10 \%$ had the Greek type. These results are generally in accordance with our results. A Thai group of authors (7), in their study on a population 
Table 2. Length of right foot $(\mathrm{cm})$

\begin{tabular}{|c|c|c|c|c|c|c|c|c|c|}
\hline SEX & $\begin{array}{c}\text { AGE } \\
\text { (years) }\end{array}$ & $\mathrm{N}$ & $\bar{X}$ & $\begin{array}{l}\text { St. } \\
\text { dev. }\end{array}$ & Min. & Max. & Q1 & Med. & Q3 \\
\hline \multirow{6}{*}{ 怘 } & 2 & 242 & 13.55 & 1.06 & 10.3 & 16.2 & 12.8 & 13.5 & 14.3 \\
\hline & 3 & 214 & 15.36 & 1.13 & 12.5 & 19.1 & 14.5 & 15.3 & 16.1 \\
\hline & 4 & 221 & 16.65 & 1.08 & 12.9 & 20.8 & 16 & 16.6 & 17.3 \\
\hline & 5 & 196 & 17.76 & 1.09 & 15.5 & 20.8 & 17 & 17.7 & 18.45 \\
\hline & 6 & 259 & 18.89 & 1.09 & 15.8 & 22.2 & 18.1 & 19 & 19.6 \\
\hline & 7 & 238 & 19.66 & 1.21 & 16.5 & 23.2 & 18.9 & 19.5 & 20.4 \\
\hline \multirow{6}{*}{ ڤ્ટ } & 2 & 149 & 14.16 & 1.09 & 10.1 & 17.3 & 13.5 & 14.1 & 14.9 \\
\hline & 3 & 181 & 15.74 & 1.22 & 11.2 & 18.8 & 15 & 15.7 & 16.6 \\
\hline & 4 & 263 & 16.87 & 1.07 & 13.8 & 19.9 & 16.2 & 16.9 & 17.7 \\
\hline & 5 & 245 & 18.00 & 1.04 & 15.2 & 21.8 & 17.4 & 18 & 18.7 \\
\hline & 6 & 288 & 19.09 & 1.32 & 15.8 & 30.3 & 18.4 & 19 & 19.8 \\
\hline & 7 & 249 & 19.95 & 1.43 & 16.5 & 29.8 & 19.1 & 20 & 20.8 \\
\hline
\end{tabular}

of children aged 7-12 years, grouped foot shapes into 4 groups: short and stubby, small and narrow, small, and wide. The average length of the foot in boys aged 7 years was $17.5 \mathrm{~cm}$, while in girls it measured $15 \mathrm{~cm}$ on average. In our study, the corresponding lengths of feet in boys and girls aged 7 years were $20 \mathrm{~cm}$ and $19.5 \mathrm{~cm}$ respectively, which is a significant difference from those of Thai children. The feet of Croatian boys are longer by $2.5 \mathrm{~cm}$, while the feet of girls are longer by $4.5 \mathrm{~cm}$. Foot length is taken as a basic reference unit which allows for follow up of foot length and is highly standardized for each country, though it varies according to geographic localization and ethnic differences. Foot length is most often determined anthropometrically (1-12). The results of a study conducted on a population of 20,000 Chinese children showed that the most common foot shape was the intermediate type and that there is no significant change in foot shape after measuring length and width by 12 years of age (8). In this study, Ran et al. measured the average foot length in Chinese children aged 4-6 years, which measured $17.2 \mathrm{~cm}$ in boys and $16.9 \mathrm{~cm}$ in girls, which is roughly $1 \mathrm{~cm}$ shorter than the lengths in same-aged

Table 3. Length of left foot $(\mathrm{cm})$

\begin{tabular}{|c|c|c|c|c|c|c|c|c|c|}
\hline SEX & $\begin{array}{c}\text { AGE } \\
\text { (years) }\end{array}$ & $\mathrm{N}$ & $\bar{X}$ & $\begin{array}{l}\text { St. } \\
\text { dev. }\end{array}$ & Min. & Max. & Q1 & Med. & Q3 \\
\hline \multirow{6}{*}{ 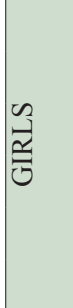 } & 2 & 242 & 13.54 & 1.06 & 10.5 & 16.3 & 12.8 & 13.5 & 14.4 \\
\hline & 3 & 214 & 15.35 & 1.12 & 12.6 & 19 & 14.5 & 15.3 & 16 \\
\hline & 4 & 221 & 16.62 & 1.09 & 13 & 21 & 16 & 16.6 & 17.2 \\
\hline & 5 & 196 & 17.72 & 1.09 & 15.3 & 20.6 & 16.9 & 17.65 & 18.4 \\
\hline & 6 & 259 & 18.87 & 1.28 & 15.7 & 29.6 & 18 & 18.9 & 19.6 \\
\hline & 7 & 238 & 19.62 & 1.20 & 16.5 & 23.2 & 18.9 & 19.55 & 20.4 \\
\hline \multirow{6}{*}{ 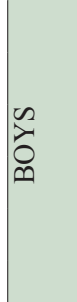 } & 2 & 149 & 14.16 & 1.06 & 10.1 & 17.1 & 13.5 & 14.1 & 14.8 \\
\hline & 3 & 181 & 15.74 & 1.20 & 11 & 19 & 15 & 15.7 & 16.5 \\
\hline & 4 & 263 & 16.84 & 1.08 & 13.9 & 20 & 16.1 & 16.8 & 17.6 \\
\hline & 5 & 245 & 17.95 & 1.10 & 12.8 & 21.6 & 17.2 & 17.9 & 18.6 \\
\hline & 6 & 288 & 19.04 & 1.15 & 15.6 & 24 & 18.3 & 19 & 19.8 \\
\hline & 7 & 249 & 19.92 & 1.32 & 16.3 & 24.1 & 19.1 & 19.9 & 20.7 \\
\hline
\end{tabular}


Table 4. Foot shape in boys

\begin{tabular}{|c|c|c|c|c|c|}
\hline AGE & FOOT SHAPE & $\begin{array}{c}\text { RIGHT } \\
\text { FOOT }\end{array}$ & $\begin{array}{l}\text { LEFT } \\
\text { FOOT }\end{array}$ & TOTAL & $\%$ \\
\hline \multirow[t]{3}{*}{2} & EGYPTIAN & 122 & 122 & 244 & 81.88 \\
\hline & GREEK & 23 & 23 & 46 & 15.44 \\
\hline & SQUARE & 4 & 4 & 8 & 2.68 \\
\hline \multirow[t]{3}{*}{3} & EGYPTIAN & 155 & 155 & 310 & 85.64 \\
\hline & GREEK & 18 & 18 & 36 & 9.94 \\
\hline & SQUARE & 8 & 8 & 16 & 4.42 \\
\hline \multirow[t]{3}{*}{4} & EGYPTIAN & 231 & 231 & 462 & 87.83 \\
\hline & GREEK & 24 & 24 & 48 & 9.13 \\
\hline & SQUARE & 8 & 8 & 16 & 3.04 \\
\hline \multirow[t]{3}{*}{5} & EGYPTIAN & 197 & 197 & 394 & 80.41 \\
\hline & GREEK & 52 & 52 & 70 & 14.29 \\
\hline & SQUARE & 22 & 22 & 26 & 5.30 \\
\hline \multirow[t]{3}{*}{6} & EGYPTIAN & 214 & 214 & 428 & 74.31 \\
\hline & GREEK & 54 & 54 & 108 & 18.75 \\
\hline & SQUARE & 22 & 22 & 44 & 7.64 \\
\hline \multirow[t]{3}{*}{7} & EGYPTIAN & 179 & 179 & 358 & 71.89 \\
\hline & GREEK & 52 & 52 & 104 & 20.88 \\
\hline & SQUARE & 18 & 18 & 36 & 7.23 \\
\hline
\end{tabular}

Croatian children. In our country, a study measuring foot length has been conducted on a sample of 30866 individuals for purposes relevant to the shoemaking industry (9). The average foot length in children aged 1 year measured approximately $12.5 \mathrm{~cm}$, while at 7 years this value reached $20 \mathrm{~cm}$, which is in accordance with our value for this age groups. In 2001, Prado-Leon and coauthors (10) published their results of anthropometric measurements in a sample of 4759 Mexican children aged 6-11 years. Foot length was measured as well, among other things. At 6 years of age, the mean foot length of boys was found to be $18.5 \mathrm{~cm}$, while in girls it was $18.2 \mathrm{~cm}$. At 7 years of age, these measures reached $19.3 \mathrm{~cm}$ in boys and $19 \mathrm{~cm}$ in girls. Comparing this with our results, Croatian children have longer feet (boys and girls at 6 years of age averaged $19 \mathrm{~cm}$; at 7 years, boys averaged $20 \mathrm{~cm}$ and girls averaged $19.5 \mathrm{~cm}$ ) which are $5 \mathrm{~mm}$ longer in boys and $7 \mathrm{~mm}$ longer in girls. A group of authors from Malaysian (11) have also measured foot length in a group of Malaysian children aged 5 and 6 years. In their sample of 303 children, the average foot length for boys aged 5 years was $17.18 \mathrm{~cm}$, while in girls it was $17.2 \mathrm{~cm}$. At 6 years of age, foot length in boys measured $17.82 \mathrm{~cm}$, while in girls it was $17.81 \mathrm{~cm}$. Foot length of Croatian children is considerably longer than Malaysian children, particularly at 6 years of age - even at 5 years of age, Croatian boys' feet average $18 \mathrm{~cm}$ in length, while at 6 years it averages $19 \mathrm{~cm}$. In girls at 5 years of age we averaged $17.7 \mathrm{~cm}$, while at 6 years of age foot
Table 5. Foot shape in girls

\begin{tabular}{|c|c|c|c|c|c|}
\hline AGE & FOOT SHAPE & $\begin{array}{l}\text { RIGHT } \\
\text { FOOT }\end{array}$ & $\begin{array}{l}\text { LEFT } \\
\text { FOOT }\end{array}$ & TOTAL & $\%$ \\
\hline \multirow[t]{3}{*}{2} & EGYPTIAN & 203 & 203 & 406 & 83.89 \\
\hline & GREEK & 35 & 35 & 70 & 14.46 \\
\hline & SQUARE & 4 & 4 & 8 & 1.65 \\
\hline \multirow[t]{3}{*}{3} & EGYPTIAN & 175 & 175 & 350 & 81.78 \\
\hline & GREEK & 35 & 35 & 70 & 16.35 \\
\hline & SQUARE & 4 & 4 & 8 & 1.87 \\
\hline \multirow[t]{3}{*}{4} & EGYPTIAN & 182 & 182 & 364 & 82.35 \\
\hline & GREEK & 32 & 32 & 64 & 14.48 \\
\hline & SQUARE & 7 & 7 & 14 & 3.17 \\
\hline \multirow[t]{3}{*}{5} & EGYPTIAN & 144 & 144 & 288 & 73.47 \\
\hline & GREEK & 40 & 40 & 80 & 20.41 \\
\hline & SQUARE & 12 & 12 & 24 & 6.12 \\
\hline \multirow[t]{3}{*}{6} & EGYPTIAN & 190 & 190 & 380 & 73.36 \\
\hline & GREEK & 55 & 55 & 110 & 21.23 \\
\hline & SQUARE & 14 & 14 & 28 & 5.41 \\
\hline \multirow[t]{3}{*}{7} & EGYPTIAN & 186 & 186 & 372 & 78.15 \\
\hline & GREEK & 44 & 44 & 88 & 18.49 \\
\hline & SQUARE & 8 & 8 & 16 & 3.36 \\
\hline
\end{tabular}

length reaches $19 \mathrm{~cm}$. In a pilot study in the Republic of Croatia in 2004, on a sample size of 1602 children aged 1 to 16 years, the Egyptian foot shape was most common, followed by the Greek type in 79 children, and only 2 children had square type feet (5). The average foot length at 1 year of age was found to be $12.65 \mathrm{~cm}$, while at 7 years it reached $19.79 \mathrm{~cm}$. In individual sex/age groups, there was no statistically significant difference between left and right feet. Of all of the studies which have to our knowledge been published in indexed journals in the past 20 years, and with which we have compared our results, we can conclude that preschool children in the Republic of Croatia have the longest feet.

\section{CONCLUSION}

Knowledge of anthropometric parameters for obtaining a standard foot dimensions for our population is required for normal growth and development of the foot. Obtaining anthropometric measurements for developing feet is very important because the data acquired from the measurements enables the production of ergonomic children's footwear. An ergonomic children's shoe allows for the foot to grow and develop unimpeded and prevents the development of foot deformities. In order to produce children's footwear, it is necessary to create shoe molds based on the specific foot shapes and sizes among the population of children. Shoes in Croatia today are produced based 
on Italian, German and other molds, which do not necessarily cater to the unique foot dimensions of children in Croatia. Foot length is the basis for size comparison and determination of foot shape. The results obtained demonstrate that in male and female children from 2 to 7 years of age, the foot grows in length steadily every year and that there is no difference between the left and right feet. The most common shape is the Egyptian type, followed by the Greek type, and with a small contribution from the square type in all sex/age groups. This research study is a part of a database which will facilitate the monitoring and frequency of congenital and acquired foot deformities (eg. hallux valgus development). The research results will be used to define the standard average foot lengths and widths among children in Croatia.

\section{REFERENCES}

1. STRACKER O 1960 Der Kinderfuss und seine Beschuchung. Arhiv orthop Unfall-Chir 52: 390-412

2. DEBRUNNER HU 1965 Wachstum und Entwicklung des Fusses beim Jugendlichen, Ferdinand Enke, Verlag, Stuttgart, 3.

3. CHENG JC, LEUNG SS, LEUNG AK, GUO X, SHER A, MAK AF 1997 Change of foot size with weightbearing. A study of 2829 children 3 to 18 years of age, Clin Orthop Relat Res 342: 123-31
4. BLAIS M, GREEN WT, ANDERSON M 1956 Lenghts of the Growing Foot. J Bone Joint Surg Am 38: 998-1000

5. VRDOLJAK J, BRALIĆ I, MILIČIĆ G, IRHA E, BOJIĆ D, VRDOLJAK O 2004 Antropometrijske izmjere stopala u rastu. Paediatria Croatica 48: 117-120

6. IRHA E, HUSIĆ I, ŽIVKOVIĆ O, LABAŠ M 1990 Stopalo urbanog stanovništva. OP 90, Zbornik povzetkov 32 .

7. RAWANGONG S, CHATTONG J, BOONCHOUYTAN W 2011 Foot Anthropometry of Primary School Children in the South of Thailand. World Academy of Science, Engineering and Technology 399: 404

8. RAN L, ZHANG X, CHAO C, LIU T 2011 Anthropometric Measurement of the Feet of Chinese Children. Digital Human Modeling Lecture Notes in Computer Science 6777: 30-36

9. UJEVIĆ D, DOLEŽAL K, LEŠINA M 2007 Analysis of Anthropometric Measurements for the Footwear Industry. Business Excellence 1: 171-182

10. PRADO-LEÓN LR, AVILA-CHAURAND R, GONZÁLEZMUÑOZ EL 2001 Anthropometric study of Mexican primary school children. Appl Ergon 32: 339-45

11. BARI SB, OTHMAN M, MOHD SALLEH N 2010 Foot Anthropometry for Shoe Design among Preschool Children in Malaysia. Pertanika J. Soc. Sci. \& Hum 18: $69-79$

12. ANDERSON M, BLAIS M, GREEN WT 1956 Growth of the normal foot during childhood and adolescence. Length of the foot and interrelations of foot, stature, and lower extremity as seen in serial records of children between 1-18 years of age. AM J Phys Anthropo 14: 287-308. https://doi.org/10.1002/ajpa.1330140221 